\title{
MANUEL BOMFIM
}

Natural de Sergipe, Manuel Bomfim formou-se na Faculdade de Medicina do Rio de Janeiro em 1890. Ingressou no magistério oito anos depois, lecionando Educação Moral e Cívica na Escola Normal do Rio de Janeiro, na qual assumiu logo depois a cátedra de Pedagogia e Psicologia.

Em viagem a Paris, realizada no ano de 1902, desenvolveu seus estudos em Psicologia, tendo freqüentado o Laboratório de Psicologia anexo à Clínica Jouffroy, em Saint’Anne. Neste período, Bomfim estudou com George Duma e Alfred Binet, com quem planejou a instalação do primeiro Laboratório de Psicologia Brasileiro, instalado em 1906 no Pedagogium, do qual foi diretor por quinze anos. De volta ao Brasil, foi nomeado diretor da Instrução Pública.

Autor de vasta obra, escreveu sobre História do Brasil e da América Latina, Sociologia, Medicina, Zoologia e Botânica, além de vários livros didáticos, entre os quais estão alguns de Língua Portuguesa, em co-autoria com Olavo Bilac. Bomfim escreveu ainda, na área de Psicologia e Educação, as obras Lições de Pedagogia (1915) e Noções de psychologia (1916), utilizadas como suporte para as suas aulas na Escola Normal.

Na obra Pensar e Dizer: estudo do símbolo no pensamento e na linguagem (1923), Bomfim demostra vasta cultura geral e domínio das mais importantes correntes de Psicologia de sua época. Também são de sua autoria os livros: O methodo dos testes (1926); Cultura do povo brasileiro (1932); Crítica à Escola Activa, O fato psychico, As alucinações auditivas do perseguido e O respeito à criança.

Sua obra escrita revela um pensador original e não articulado às idéias correntes na época. Sua interpretação de Brasil apoia-se na análise histórica da colonização empreendida ela metrópole, na exploração e na espoliação das riquezas brasileiras, com conseqüências sobre as condições culturais do povo. Assim, Manuel Bomfim defende a expansão da educação pública como meio privilegiado para a construção de uma sociedade democrática, calcada na liberdade que somente poderia ser atingida pelo acesso de todos ao saber.

Suas concepções de Psicologia, fenômeno psicológico e método para seu estudo também seguem caminhos diversos do corrente na época. Ele considerava o fenômeno psicológico como eminentemente histórico-social, constituído nas relações entre consciência, mediatizadas pela linguagem, compreendida como produto e meio da socialização. Bonfim critica a pesquisa realizada em laboratório, considerando que a complexidade do psiquismo não seria passível de ser apreendida em condições tão restritas e artificiais. Ele propôs o método interpretativo para o estudo do psiquismo, baseado no estudo das múltiplas manifestações humanas, no qual deveria ser incluído o estudo da história forjada pela humanidade ao longo do tempo, expressão maior da inteligência e fonte para sua compreensão.

É possível dizer que Bomfim antecipou algumas idéias posteriormente adotadas pela Psicologia, como as de Vigotski e Piaget, assim como teria antecipado as idéias de Ernest Bloch e Antonio Gramsci em sua interpretação da sociedade. Entretanto, Bonfim permaneceu esquecido na historiografia brasileira, fenômeno esse que pode ser parcialmente explicado por suas diferenças e pela contraposição de seus pensamentos para a época. 